\title{
Stylistic Analysis of The Great Gatsby from Context Category
}

\author{
Xiangqi Liu \\ School of Foreign Languages, Qingdao University of Science and Technology, Qingdao, China \\ Email: shirley780204@yahoo.com.cn
}

\begin{abstract}
The thesis tries to adopt the method used by Leech and Short in their book Style in Fiction to make a relatively overall and objective analysis of the novel's language from the context category. From the context perspective, point of view and modes of speech presentation are used to produce special stylistic effects. In the category of point of view, the author makes use of both limited first-person witness perspective and shifts of narrative perspective -- the adoption of these narrative techniques is closely related to the theme of the novel. Modes of speech presentation in the novel, which involve Direct Speech, Indirect Speech, Free Indirect Speech and Free Direct Speech, serve to adjust distance or create stylistic effects the author aims to achieve.
\end{abstract}

\section{Index Terms - context category, point of view, modes of speech presentation}

This thesis is devoted to a general analysis of the stylistic features in Fitzgerald's The Great Gatsby from the context category. Our analysis is based on Leech and Short's model which is marked by a neat progression from one category to another. The other categories are lexical categories, grammatical categories, and figures of speech.

\section{POINT OF VIEW}

The Great Gatsby is valued for the vividness with which it depicts a historical era; perhaps more than by any other American novels written in the 1920s, we are convinced that we hear the voices of people speaking from that decade. In such a novel with interweaving plots and varying scenes, the author's selection of point of view becomes a primary factor in its impact and effectiveness. The Great Gatsby can be best described as a narration of a series of events as viewed from the point of view of "I" -- Nick Carraway, a witness in the novel, around which the story unfolds, while the shift of point of view is also noticeable. While Fitzgerald's choice to present the plot mainly through the eyes of first-person narrator presents certain limitations, it provides the means to relate the tone and message of the novel as a whole. But how does this narrative point of view achieve its special stylistic effects? With this question in mind we will examine the narrative methods of this novel.

\section{A. Limited First-person Witness Narrative}

In The Great Gatsby, the author writes the story mainly from limited first-person point of view and "I", Nick Carraway, is the narrator who presents a story of what he sees and hears.

At the very beginning of the novel, for example, the author writes:

When I came back from the East last autumn I felt that I wanted the world to be in uniform and at a sort of moral attention forever; I wanted no more riotous excursions with privileged glimpses into the human heart. Only Gatsby, the man who gives his name to this book, was exempt from my reaction-Gatsby, who represented every thing for which I have an unaffected scorn. (p. 8)

In the extract quoted above, we know from such phrases as "I felt, I wanted, and privileged glimpses into the human heart" that it is "I" - Nick -- who is narrating the story; and "moral attention, riotous excursions" and "unaffected scorn" suggest that Nick narrates with evaluation of Gatsby and value judgment on other characters. And Nick's judgment here "Gatsby turned out all right at the end" has in fact set the tone of the narration of the whole story.

Nick is designed as a witness, so he is initially placed at the edge of the story: he is the neighbor of Gatsby in West Egg, a distant cousin of Daisy and a classmate of Tom at Yale. The remote relationship is gradually strengthened until he becomes, though reluctantly, involved in Gatsby's pursuit of Daisy. Nick is forced to meet Tom's mistress Myrtle Wilson; he is invited to Gatsby's enormous cocktail party; Gatsby takes him to New York where he is confronted with Meyer Wolfsheim, Gatsby's business associate. This way of narration as a result gives the reader a deep insight into the life and situation of the hero. In addition, Nick's position becomes such that he is able to witness and report for the benefit of the reader, his own understanding of what he sees, and his feelings, yet he is able to stay at the same time quite detached from the action itself.

As a witness, Nick is the medium by which those people's voices are heard and, as the principal speaker in the text, he serves as a translator of the dreams and social ambitions of the people who surround him. There are three ways by which Nick keeps himself on stage, informing the reader of what is happening or has happened in The Great Gatsby. Other than the way of narrating the events Nick himself has experienced, there are two other means for him to convince the reader of the development of this story: if he is not present on a particular occasion, he gets the information from 
someone who is present-- from Jordan Baker, for example, who tells him about Gatsby's courtship of Daisy in Louisville; or from the Greek, Michaelis, who tells him about the death of Myrtle Wilson. Occasionally he reconstructs an event from several different sources-- the newspapers, the servants' gossiping and even his own imagination. Through Nick's information derived from many different sources, Fitzgerald makes a compact and well-knit structure of the story. As in Fitzgerald's writing, the narrator is careful throughout the novel never to tell us things that he could not have known, his retrospect narrative is from a limited first-person point of view, and he can be defined as a reliable narrator as is evident when he claims himself "inclined to reserve all judgments". (p. 7)

This limited thus reliable first-person point of view is remarkably helpful for the reader to understand the characters in the novel and the theme of the American Dream because this perspective offers the story a kind of objectivity and reliability, and offers readers not only the events themselves but also insights into these events by seeing how the narrator reflects upon them.

Believing that the narrator is a reliable witness with reserved judgment, the reader tends to trust him with little doubt. Consequently, the reader's attitude would be assimilated to the narrator's. When he observes experiences surrounding the mysterious figure of Jay Gatsby, Nick undergoes a transformation himself, so does the reader. By means of reliable witness narrator, Fitzgerald enables the reader to sense the shallow emotional depth Tom Buchanan is capable of experiencing and his apparent harshness of attitude towards others. The brutality of Tom towards his mistress, Myrtle Wilson, as presented by Nick, is highly demonstrative of this fact. Thus, Nick, and in turn the reader, gets more and more disgusted with Nick's former friends, which Nick evaluates by saying:

They were careless people, Tom and Daisy-they smashed up things and creatures and then retreated back into their money or their vast carelessness, or whatever it was that kept them together, and let other people clean up the mess they had made ... (p. 170)

In comparison, through the narrator, we see Gatsby as generally being a physically and emotionally reserved person, and have a remarkable, brief insight into Gatsby's desire for Daisy. Gatsby's continuous pursuit of his pure dream -repeating his love with Daisy -- is in sharp contrast with Tom's infidelity, cruelty and Daisy's cowardice. Thus by limited first-person witness narrative, Fitzgerald places the reader in direct touch with the action, eliminating himself, as author, entirely, whereby a kind of intimacy is achieved. The narrator seems to address the reader directly and from the heart, sharing his personal observations and insights with an interested listener. With regard to the author, he stands outside the story and takes an unprejudiced attitude towards what the characters say and how they behave. This narrative technique enables the reader to understand better the narrator's innermost thoughts, and also makes possible objective and natural appraisals on Gatsby and other characters, and the author, Fitzgerald, retreating into the backstage, communicates with the reader secretly and helps to bring about the final acceptance and understanding of the hero by the reader.

When the reader gains insights into the characters, he understands the theme of the American Dream more; and the insights into both the characters and the theme depend on the narrator's narration of the story.

Besides that of Gatsby's romantic love for Daisy, the narration of Gatsby's identity is also crucial to the theme. In the first three chapters of the novel, stretched over much of the narrative is the mystery of Gatsby's origins: Gatsby is rumored to be a nephew or a cousin of Kaiser Wilhelm, the much-despised ruler of Germany, and Gatsby claims himself to be the scion of a wealthy, English-educated family; some say Gatsby has been a German spy during the war, and still some say that he has even killed a man. But the narrator eventually unfolds that Jay Gatsby is actually James Gatz, the son of "shiftless and unsuccessful farm people from North Dakota" (p. 45); and Gatsby springs from "his Platonic conception of himself" (p. 95).The narrator hence supplies the reader with the information that Gatsby's identity is an invention, and that Gatsby holds to believe that the past can be repeated and a man can create himself anew by the exercise of his own will and energy-- all of which imply Gatsby's symbolic meaning of the American self-made and self-reliant man, an important belief of the American Dream. As a result, the reader is impressed greatly by the appalling image of the hero whose tragic destiny is to be in association with the American Dream.

Gatsby's general hospitality and mysteriousness as described by the narrator creates an air of splendor and establishes him as a source of profound curiosity in the minds of others. His eventual failure in his attempt to transcend his social status and get integrated with the exclusive society to which Daisy belongs demonstrates the corruption of the American Dream. Thus it is the narrator who directs us to the dignity and depth of Gatsby's character, and intimates the relation of Gatsby's tragedy to the American Dream. The retrospective narrative, therefore, is designed to lament the inevitability of the decline of the American Dream. Fitzgerald, through what the first-person narrator perceives and the changes he undergoes, comments specifically on the society of his times.

Maybe a more or less negative aspect is to be mentioned: by using I-narration, it is impossible for Fitzgerald to state those events which Nick has not experienced or is not told about other than by Nick's imagination. But in this case, this feature of I-narration is an advantage as it maintains the myth of Gatsby and builds up suspense. Therefore a conclusion may be drawn that Fitzgerald chooses limited I-narration to have the possibility to arrange the plot and to render the story immediacy, credibility and authenticity. By writing from Nick's point of view-- the limited first-person point of view, Fitzgerald is able to give the whole novel a greater touch of realism than he could have by presenting Gatsby through the eyes of an omniscient narrator.

Within the frame of limited first-person witness narrative, there are some shifts of narrative perspective, either with 
switches to third-person point of view or to second-person point of view.

\section{B. Alternating Third-person Point of View}

As is discussed in the previous sections, Nick's eyes provide not only a skillful, but also a necessary framework for the entire novel. But, much as Booth puts it, a story could not have been written from a consistent point of view without stretching its length and losing its taut comic force. (Booth, 1961: 14) In most cases the author may choose one point of view throughout the story to dominate the narrative, but shift the point of view in order to sustain interest, create suspense, or achieve characterization, etc.

Fitzgerald employs the first-person observer or participant perspective in telling the story. Thereby the novel becomes more natural, authentic, and credible through the narration of the eye-witness. The reader is able to merge into Nick's story readily, and establish intimacy with the characters emotionally. Also, the limitation of first-person narration enables the narrator to avoid scenes that his insights could not handle. However, Fitzgerald must sometimes have found the first-person perspective inadequate for the credibility of his moral stance and will not accept the limitation of this self-imposed restriction. As a result, he constantly draws back on different points of view. By shifting the narrative perspectives, Fitzgerald allows us to transcend the narrative time and space limited to Nick only.

The following is one of the many cases in which the point of view is shifted from the first-person to the third-person:

For over a year he had been beating his way along the South Shore of Lake Superior as a clam-digger and a salmon-fisher or in any other capacity that brought him food and bed. His brown, hardening body lived naturally through the half-fierce, half-lazy work of the bracing days ....

But his heart was in a constant, turbulent riot. The most grotesque and fantastic conceits haunted him in his bed at night ... Each night he added to the pattern of his fancies until drowsiness closed down upon some vivid scene with an obvious embrace. For a while these reveries provide an outlet for his imagination; they were a satisfactory hint of the unreality of reality, a promise that the rock of the world was founded securely on a fairy's wing. (p. 95)

In the extract quoted above, the first paragraph narrates Gatsby's work experience from outside, while the second paragraph focuses on the thoughts and feelings of Gatsby. It is obvious that the author adopts a limited omniscient third-person point of view, in which the early year of Gatsby's life has been vividly revealed, and we are able to see the hardship Gatsby has undergone and also his persistent, mysterious nature. The story finally proves to be fairly pathetic and thought-provoking.

Another example comes from Chapter 6 of the novel, in which Nick assumes an omniscient understanding of Gatsby:

... One autumn night, five years before, they had been walking down the street when the leaves were falling, and they came to a place where there were no trees and the sidewalk was white with moonlight .... Out of the corner of his eye Gatsby saw that the blocks of the sidewalks really formed a ladder and mounted to a secret place above the trees-he could climb to it, if he climbed alone, and once there he could suck on the pap of life, gulp down the incomparable milk of wonder.

His heart beat faster and faster as Daisy's white face came up to his own. He knew that when he kissed this girl, and forever wed his unutterable vision to her perishable breath, his mind would never romp again like the mind of God. So he waited, listening for a moment longer to the tuning-fork that had been struck upon a star. Then he kissed her. At his lips' touch she blossomed for him like a flower and the incarnation was complete. (pp. 106-107)

When reading the passage describing Gatsby's overwhelming feelings, such words as "Gatsby saw", "he knew" and the modal verb "could", together with the sentence "His heart beat faster and faster" clearly indicate that the narrator shows completely the interior world of the character and even knows more than the character, therefore we can assume that it is narrated through omniscient third-person point of view. Through this omniscient narrative perspective, the author succeeds in his attempt to reveal the idealistic inner world of Gatsby. Besides, these paragraphs begin on the outside edge of Gatsby's mind, and then go deeper and deeper inside. The shift of point of view, then, is the basic technique fiction writers may use to manipulate distance between the reader and the characters.

In the construction of the story, Fitzgerald handles the multi-dimensional point of view exquisitely. Take Chapter 8 of the novel for example. It dodges from one perspective to another in an effort to achieve some expanse, whereby we are in Nick's mind, Gatsby's mind and even Daisy's mind.

When they met again, two days later, it was Gatsby who was breathless, who was, somehow, betrayed....Gatsby was overwhelmingly aware of the youth and mystery that wealth imprisons and preserves, of the freshness of many clothes, and of Daisy, gleaming like silver, safe and proud above the hot struggles of the poor ....

On the last afternoon before he went abroad, he sat with Daisy in his arm for a long, silent time. It was a cold fall day, with a fire in the room and her cheeks flushed. Now and then she moved and he changed his arm a little, and once he kissed her dark shinning hair. The afternoon had made them tranquil for a while, as if to give them a deep memory for the long parting the next day promised. They had never been closer in their month of love, nor communicated more profoundly one with another..... (pp. 142-143)

At this point there are two perspectives combined here: one from Nick's ironic perspective, telling Gatsby's love for Daisy, and one from third-person omniscient point of view, looking into Gatsby and Daisy's hearts and knowing that "they had never been closer in their month of love, nor communicated more profoundly one with another", which seems to understand much more than they themselves do; and these two perspectives share the same voice. This narrative stance clearly reveals the kind of qualities in Daisy that are actually attractive to Gatsby, and through it Nick 
confidentially communicates his satiric attitude.

Then one paragraph later, we see things from Daisy's perspective:

Through this twilight universe Daisy began to move again with the season; suddenly she was again keeping half a dozen dates with half a dozen men, and drowsing asleep at a dawn with the beads and chiffon of an evening dress tangled among dying orchids on the floor beside her bed. And all the time something within her was crying for a decision. She wanted her life shaped now, immediately and the decision must be made by some force -- of love, of money, of unquestionable practicality -- that was close at hand. (p. 144)

The above mentioned narrative is a story told by Gatsby, but he was at that time in European battlefields far away from the place where the story happened. He was not supposed to know what Daisy was doing -- "Daisy began to move again" -- and what she was thinking -- "something within her was crying for a decision and she wanted ...", but nevertheless, a vivid and detailed description of Daisy's condition at that moment is given, which consequently brings about a kind of authenticity and truism. Surely this is a typical example of omniscient third-person point of view, in which the author stands outside the story, reveals the feelings and thoughts of the characters freely in time and space, thus a deeper understanding of Daisy is obtained.

\section{Switching to Second-person Point of View}

Another perspective switch worth following up in this novel is the second-person point of view. Although the second-person viewpoint, in which the narrator tells a listener what he or she has done and said, using "you", is possible, it is rare and negligible in practice because in effect the second-person structure requires a first-person speaker who tells the listener -- the "you" of the narration -- what he or she did at a past time. However, in The Great Gatsby, Fitzgerald deliberately interposes the second-person narration, just as the following example:

.... Occasionally a line of grey cars crawls along an invisible track, gives out a ghastly creak and comes to rest, and immediately the ash-grey men swarm up with leaden spades and stir up an impenetrable cloud, which screens their obscure operations from your sight.

But above the grey land and the spasms of bleak dust which drift endlessly over it, you perceive, after a moment, the eyes of Doctor T. J. Eckleburg .... (p. 26)

Here the author adopts a second-person stance, addressing the listener or reader as you, describing the valley of ashes as if the narrator were observing it from the sight of the reader, in which the distance between the reader and the narrator, and the narrated story as well has been shortened substantially.

The author also deliberately switches first-person point of view to second-person point of view when the narrator meets Gatsby for the first time:

He smiled understandingly-much more than understandingly. It was one of those rare smiles with a quality of eternal reassurance in it, that you may come across four or five times in life. It faced-or seemed to face-the whole eternal world for an instant, and then concentrated on you with an irresistible prejudice in your favor. It understood you just as far as you wanted to be understood, believed in you as you would like to believe in yourself, and assured you that it had precisely the impression of you that, at your best, you hoped to convey. (p. 49)

Again this description of Gatsby from second-person point of view gives an illusion that the reader is having a face-to-face contact with him. The reader seems to be able to feel Gatsby's understanding smile and his favorable concentration, thus the distance between the reader and the protagonist is greatly shortened. This shortened distance gains more sympathy for Gatsby when his tragedy is revealed.

In general, the writing of this novel is not in a consistent perspective. Instead, the narrative viewpoint is motivated by the theme of the novel -- the American Dream and its decadence and keeps changing in accordance with the progress of the story. As mentioned earlier, the American Dream reflected on Gatsby consists of two aspects: his love for Daisy and his identity in the wealthy world. If we want to get insights into the theme, we must get to know who Gatsby is and why he loves Daisy. Since the story is presented from the first-person witness point of view, we are sometimes at a loss what happened in Gatsby's early life. In this case, the switch from first-person point of view to third-person omniscient which mainly presents Gatsby's past enables the author to give some clues about Gatsby's American Dream. On the other hand, the switch to second-person point of view provide ways to adjust narrative distance and convey the narrator's emotional attitude. Hence, through the multi-dimensional perspective narration, the reader is capable of obtaining different moral and emotional judgment on which the evaluation of the characters and their actions are based. Moreover the employment of the multi-perspective technique in The Great Gatsby makes sure of the stereoscopic effect and the reader's participation in the creation of the novel. If Fitzgerald had employed only the first-person point of view, though it can be used to withhold information from the reader, particularly information not available to the narrator, our sense of this drama would be significantly diminished.

\section{SPEECH PRESENTATION}

The Great Gatsby is a special portrayal of an American man rising from rags to riches only to find that whatever benefits his wealth may afford, it cannot grant him the privileges of class and status. In his ironic rendering of Gatsby as a romance hero, the author would appear highly critical of the capitalist aspiration, but the author's irony does not always undercut the American Dream upon which Gatsby's fantastic world is founded, rather it locates the reader in a 
position to detach himself and look from a distance in the "foul dust" that gathers in Gatsby's wake. And this position is achieved through, other than point of view, different modes of speech presentation, through the author's decision of being in what way to convey his story and depict his characters -- directly transmitting the message through characters' direct speech or indirectly by the narrator's narration. Fitzgerald renders his story through a range of means like alternations between Direct and Indirect Speech; between Free Indirect Speech and Free Direct Speeches or through the Narrative Report of Speech Acts. The following subsections are intended to examine the stylistic effects generated by the employment of different modes of speech presentation in the novel.

\section{A. $\quad$ Direct Speech $(D S)$}

Vivid direct speeches among different characters account for more than half space of The Great Gatsby. In the story, apart from the distinctive features of vividness and immediacy, direct speeches enable the reader to identify the characters by the words they utter, with the words playing an essential role in revealing the characters' inner selves or temperaments. It is the mode of Direct Speech that provides a full scope for individual tone and expression. Also, the author's ironic stance is most prominent in his direct representation of the characters' speech, especially as he works through the linguistic resources available for such representation on those occasions when he depicts the actual world of Tom and Daisy, when he portrays one of Gatsby's gaudy parties, or the afternoon get-together in Myrtle Wilson's apartment, when the voices of the characters rise and collide. Sometimes the differentiated speeches between different characters reflect contrasts of their personalities. For example, Tom assumes that he is part of the higher class and thus he treats people with a certain sense of superiority, so when the narrator drives over to East Egg to see the Buchanans one evening, he hears such dialogues caused unexpectedly by a word "uncivilized" with no particular meaning:

"Civilization's going to pieces," broke out Tom violently. "I've gotten to be a terrible pessimist about things. Have you read The Rise of the Colored Empires by this man Goddard?"

"Why, no," answered, rather surprised by his tone.

"Well, it's a fine book, and everybody ought to read it. The idea is if we don't look out the white race will be-will be utterly submerged. It's all scientific stuff; it's been proved."

"Tom's getting very profound," said Daisy, with an expression of unthoughtful sadness. "He reads deep books with long words in them. What was that word we ..."

"Well, these books are all scientific," insisted Tom, glancing at her impatiently. "This fellow has worked out the whole thing. It's up to us, who are the dominant race, to watch out or these other races will have control of things."

"We've got to beat them down," whispered Daisy, winking ferociously toward the fervent sun.

"You ought to live in California ..." began Miss Baker, but Tom interrupted her by shifting heavily in his chair.

"This idea is that we're Nordics. I am, and you are, and you are, and ..." After an infinitesimal hesitation he included Daisy with a slight nod, and she winked at me again. "...And we've produced all the things that go to make civilization —oh, science and art, and all that. Do you see?”(p. 18)

With these actual words spoken by the characters, the author brings to full play the characters' idiolect features, thus direct speech here obviously plays an essential role in achieving vividness of characterization. These dialogues are dominated by Tom's remarks in which there is a touch of paternal contempt, adding to the impression of fractiousness. The notion that "we're Nordics -- the dominant race having produced all the things that go to make civilization" reflects his complacency and his arrogant sense of social superiority, as well as racial discrimination. On the contrary, in the early 1920s, women are regarded as accessories of men, especially after marriage. Daisy's echoing "We've got to beat them down" and Tom's minute hesitation to count Daisy as "the dominant race" seem to suggest their consciousness of her inferiority as women, and this is reinforced by Daisy's another direct speech, when she talks about her daughter and her marriage:

... Well, she was less than an hour old and Tom was God knows where. I woke up out of the ether with an utterly abandoned feeling, and asked the nurse right away if it was a boy or a girl. She told me it was a girl, and so I turned my head away and wept. "All right," I said, "I'm glad it's a girl. And I hope she'll be a fool-that's the best thing a girl can be in this world, a beautiful little fool."

"You see I think everything's terrible anyhow," she went on in a convinced way. "Everybody thinks so -- the most advanced people. And I know." (p. 22)

Hence through dialogues or direct speeches Tom's arrogance as high class and Daisy's obedience and occasional defiance and thus lack of ability to change her marriage life are vividly conveyed. These partly explain Gatsby's failure to get Daisy back later -- she is the product of her class, that is, this characterization achieved through DS anticipates the corruption of the American Dream, part of the theme of this novel. It is exemplified earlier that Gatsby tends to use long and complex sentences and his formal register recalls the immigrant struggle to master American speech and etiquette, thus the effects of characterization is generated. Another typical example is when Nick ventures into the world occupied by Gatsby and Daisy.

"If it wasn't for the mist we could see your home across the bay," said Gatsby.

"You always have a green light that burns all night at the end of your dock."

Daisy put her arm through his abruptly, but he seemed absorbed in what he had just said ....

"I adore it," exclaimed Daisy. "The pompadour! You never told me you had a pompadour -- or a yacht."...

They stood side by side examining it I was going to ask to see the rubies when the phone rang, and Gatsby took up 
the receiver.

"Yes...Well, I can't talk now ... I can't talk now, old sport ... I said a small town ... He must know what a small town is ... Well he's no use to us if his idea of a small town ..."

He rang off. (pp. 90-91)

In this extract, we can infer from Gatsby's complex sentences with perfect grammar that he uses refined English. Similarly, the type of American English Daisy uses appears to be more polished while she is around Gatsby, whom she wishes to impress. With him for instance, she uses language like: I adore it. What is interesting is that their speeches are not so refined and sophisticated around other persons or on other matters. So when Gatsby answers telephone in the dialogues, then, we hear broken sentences with obscure answers, which reveal his unwillingness for Daisy to know his "business". Daisy, on the other hand, is not afraid to call Tom "revolting" (p. 125) and her Southern roots show themselves best when she is drunk: "Tell'em all Daisy's change her mine" (p. 74). Apparently these linguistic features perform certain function of characterization. With a kind of acoustic effect, the reader seems to stand in front of the characters to listen to their speech. And as the reader knows them better, the distance between the reader and the characters is greatly shortened.

Apart from the depiction of main characters through direct speech, the characterization of many minor characters is achieved in the same way. A case in point is that of Myrtle Wilson's small talk. Myrtle is a woman who is eager to escape from the drudgery of her life into the paradise of the upper class. When the author describes Myrtle, he directly quotes what she says to reveal her characteristics. Here is what she says to a man selling dogs on their way to Tom and Myrtle's apartment:

"I'd like to get one of those police dogs; I don't suppose you got that kind? ... Is it a boy or a girl?" she asks delicately .... (p. 30)

Once at the apartment, Myrtle phones her sister, Catherine, and her friends, the McKees, to join her for a drink. As soon as Catherine arrives, these are the first words Myrtle says to her:

"My dear ... I had a woman up here last week to look at my feet, and when she gave me the bill you'd of thought she had my appendicitus out." (p. 33)

A party takes place at the apartment and while feasting her guests Myrtle says this to Mrs. McKee:

"I got to write down a list so I won't forget all the things I got to do." (p. 38)

All of her life she has aspired to refinement and propriety, a revealing case is her deliberate avoidance of using "bitch" to refer to a female dog. She is, however, far from refined, and this is evident in her continual misuse of correct grammar. She uses "got" instead of "have", does not know how to use the question form, uses "you'd of" instead of "you would have", and confuses "appendix" with "appendicitis", managing also to mispronounce the word as "appendicitis" instead of "appendicitis". Quite simply, the speech she utters reveals her lack of education and of refinement, but quite suits her identity.

In brief, direct speech in The Great Gatsby holds the distinctive features of vividness and immediacy. Being actual words the characters utter, direct speech generates a kind of acoustic effect. Besides, the employment of direct speech enables the author to bring into full play the character's idiolect features. It therefore contributes to characterization in a more distinctive and dramatic manner than any other speech forms in the novel. With the accomplishment of characterization through direct speech, the distance between reader and the characters is often shortened substantially.

\section{B. Indirect Speech (IS)}

If a character's utterance is recast in the words of the narrator, it necessarily loses both its communicative and expressive functions. Thus, IS contrasts with DS not only in immediacy but in forcefulness or impact. Such contrast enables the novelist to control "the 'light and shade' of conversation, the high-lighting and back-grounding of speech according to the role and attitude of characters. (Leech \& Short, 1981: 335) The contrast between the direct and indirect forms is constantly resorted to for characterization in this novel.

The "ashen" Wilson is depicted as a man who was his wife's man and not his own (p. 130), so let us see how the author shows him to us by means of switching between indirect and direct speech.

... Michaelis advised him to go to bed, but Wilson refused, saying that he'd miss a lot of business if he did. While his neighbor was trying to persuade him a violent racket broke out overhead.

"I've got my wife locked in up there," explained Wilson calmly. "She's going to stay there till the day after to-morrow, and then we're going to move away."

Michaelis was astonished; they had been neighbors for four years, and Wilson had never faintly capable of such statement.... So naturally Michaelis tried to find out what had happened, but Wilson wouldn't say a word -- instead he began to throw curious, suspicious glances at his visitor and ask him what he's been doing at certain times on certain days .... (p. 130)

From the extract we can see Wilson is a man faintly capable of any recognizable statement and what he says is usually recast by Indirect Speech. But when he detects his wife's infidelity, he locks his wife in. Upon his neighbor's inquiry, his IS is converted into DS. Wilson's speech seems to have gained more power from his "heroic" action. On this more specific occasion, the previous back-grounding (rendered to IS) sets off the forceful DS here.

See another example of IS which is, by contrast, fore-grounded by DS:

"Is everything all right?" he asked immediately. 
"The grass looks fine, if that's what you mean."

"What grass?" he inquired blankly. "Oh, the grass in the yard." He looked out the window at it, but, judging from his expression, I don't believe he saw a thing.

"Looks very good," he remarked vaguely. "One of the papers said they thought the rain would stop about four. I think it was The Journal. Have you got everything you need in the shape of tea?"

I took him into the pantry, where he looked a little reproachfully at the Finn. Together we scrutinized the twelve lemon cakes from the delicatessen shop.

"Will they do?" I asked.

"Of course, of course! They're fine!” and he added hollowly, “... old sport.”

... Gatsby looked with vacant eyes through a copy of Clay's Economics, ... and peering towards the bleared windows from time to time as if a series of invisible but alarming happenings were taking place outside. Finally he got up and informed me, in an uncertain voice, that he was going home.

"Why's that?"

"Nobody's coming to tea. It's too late!" he looked at his watch as if there was some pressing demand on his time elsewhere. "I can't wait all day." (pp. 81-82)

This extract describes the waiting moment when Gatsby is arranged to meet Daisy after their 5-year departure, in which DS is the pattern of speech running through the waiting time as well as the whole meeting. The inserted IS "Finally he got up and informed me, in an uncertain voice, that he was going home", therefore, becomes a deviation from the norm of the pattern. In comparison with the auditory effect of DS, IS sounds weak, and seemingly tallies with Gatsby's inner unwillingness of going home. Thus this IS vividly shows Gatsby's funny ambivalence -- anxious for Daisy's favor while worried lest he should lose her again and forever. The vivid depiction of Gatsby's struggling emotion helps to reveal Gatsby's desperate love for Daisy, part of the theme of the novel.

In contrast to these deliberate shifts between DS and IS, there are places where Fitzgerald justly produces speeches in indirect form. Before Gatsby is shot dead by Wilson, he has some conversations with his servants, here is the passage:

At two o'clock Gatsby put on his bathing-suit and left words with the butler that if any one phoned word was to be brought to him at the pool ... Then he gave instructions that the open car wasn't to be taken out under any circumstances. (p.153)

Gatsby has lingered all night outside of the Buchanans' house -- he feels strong obligation to protect Daisy and is eager to get words from her, so what he instructs here should have been of great importance to him, but instead of using more forceful DS, IS is employed, intentionally diminishing the impact of DS as if to confirm what Nick comments: "Gatsby himself didn't believe it would come, and perhaps he no longer cared" (p. 153).

The anonymous servants, on the other hand, as mere instruments in the plot, do not require DS of characterization, therefore what they utter is often displayed in IS. Consider the following example:

My Finn informed me that Gatsby had dismissed every servant in his house a week ago and replaced them with half a dozen others, who never went into West Egg Village to be bribed by the tradesmen, but order moderate supplies over the telephone. The grocery boy reported that the kitchen looked like a pigsty, and the general opinion in the village was that the new people weren't servants at all. (p. 108)

Their utterances consist of conventional reports or gossips which normally do not call for the emphasis or impact of DS, so their utterances are rendered in the mode of indirect speech which allows equal efficiency, more rapid pace and economy.

To sum up, through direct and indirect speech forms, Fitzgerald brings to the fictional world a marvelous version of characterization. Furthermore, the shifts from DS, a mode that predominates throughout, to IS serve to provide more stylistic variety.

\section{Free Indirect Speech (FIS)}

Sometimes Fitzgerald permits his narrator to reconstruct in his own words what he has been told about some events he has not witnessed, but without straightly presenting the reporting clauses, so Free Indirect Speech is used in the novel, in which the narrator's reporting voice serves to convey irony, adjusting the distances between the narrator himself and the characters he narrates, between the characters and the reader. This mode of speech presentation is not commonly used in the novel, but it is most prominent when the narrator listens to Gatsby's recalling of his story in the early life.

The following text coming from Chapter 8 of the novel is one of the examples:

It was this night he told me the strange story of his youth with Dan Cody ... I think that he would have acknowledged anything now, without reserve, but he wanted to talk about Daisy.

She was the first 'nice' girl he had ever known. In various unrevealed capacities he had come in contact with such people, but always with indiscernible barbed wire between. He went to her house, at first with other officers from Camp Taylor, then alone. It amazed him -- he had never been in such a beautiful house before. But what gave it an air of breathless intensity was that Daisy lived there -- it was as casual a thing to her as his tent out at camp was to him.... it excited him, too, that many men had already loved Daisy -- it increased her value in his eyes. He felt their presence all about the house, pervading the air with the shades and echoes of still vibrant emotions....

He might have despised himself, for he had certainly taken her under false pretences. I don't mean that he had traded on his phantom millions, but he had deliberately given Daisy a sense of security; he let her believe that he was a person 
from much the same stratum as herself ...

"I can't describe to you how surprised I was to find out I loved her, old sport. I even hoped for a while that she'd throw me over, but she didn't, because she was in love with me too. She thought I knew a lot because I knew different things from her ... Well, there I was, 'way off my ambitions, getting deeper in love every minute, and all of a sudden I didn't care. What was the use of doing great things if I could have a better time telling her what I was going to do?" (pp. 141-143)

Here, the second paragraph reveals the relationship between Gatsby and Daisy, which is narrated in Free Indirect Speech of Gatsby, and in which there is a distancing effect with remote-shift in person and back-shift in verb tense. We seem to be standing in front of Gatsby listening to his melancholy retrospection, yet are kept removed from him. Inserted in the third paragraph is the narrative voice, interposing between the reader and what Gatsby has said. Thus through FIS, Fitzgerald allows the narrator, and the reader as well, to have direct access to Gatsby's inner mind while watching his hero from a distance that enables a distinctly ironic stance -- the material things, which would have sounded mundane, become, in the narrator's narration, the enchanted objects belonging to a slightly absurd hero at the outset of his fairy-tale quest for his American Dream. From this new perspective, the reader is given the space to sense the narrator's implicit comment on the commercialism of Gatsby's romantic love. What's more, in this Free Indirect Speech, the narrator deliberately retains "nice", Gatsby's original remark on Daily. From what has happened prior to Gatsby's memory -- Daisy's running over Myrtle in a car without any stop and her intention to escape the responsibility of killing -- Nick as well as the reader is aware that Daisy is by no means a "nice" girl, thereby the discrepancy in opinions between the character and the narrator is highlighted through FIS. The substitution of Gatsby's exact word for the authorial narrator's voice makes the irony at once all the more striking. Another thing that deserves special interest here is the last paragraph quoted. This Direct Speech with excellent forcefulness and power, foiled by Free Indirect Speech, seems to suggest that in all Gatsby's dreamy memory of their "good old days", his love for Daisy is definite and unquestionable.

Another striking example of FIS can be seen in Chapter 6 of the novel:

James Gatz -- that was really, or at least legally, his name. He had changed it at the age of seventeen and at the specific moment that witnessed the beginning of Gatsby's career -- when he saw Dan Cody's yacht drop anchor over the most insidious flat on Lake Superior. It was James Gatz who had been loafing along the beach that afternoon in a torn green jersey and a pair of canvas pants, but it was already Jay Gatsby who borrowed a rowboat, pulled out to the Tuolomee, and informed Cody that a wind might catch him and break him up in half an hour.

I suppose he'd had the name ready for a long time, even then. His parents were shiftless and unsuccessful farm people -- his imagination had never really accepted them as his parents at all. The truth was that Jay Gatsby of West Egg, Long Island, sprang from his Platonic conception of himself. He was a son of God -- a phrase which, if it means anything, means just that -- and he must be about His Father's business, the service of a vast, vulgar, and meretricious beauty. So he invented just the sort of Jay Gatsby that a seventeen-year-old boy would be likely to invent, and to this conception he was faithful to the end. For over a year he had been beating his way along the south shore of Lake Superior as a clam-digger and a salmon-fisher or in any other capacity that brought him food and bed. His brown, hardening body lived naturally through the half-fierce, half-lazy work of the bracing days...But his heart was in a constant, turbulent riot. The most grotesque and fantastic conceits haunted him in his bed at night.... He told me all this very much later, but I've put it down here with the idea of exploding those first wild rumors about his antecedents, which weren't even faintly true. (pp. 94-97)

This excerpt, narrated in Free Indirect Speech of Gatsby, records his early struggling years along the south shore of Lake Superior. Through FIS, Fitzgerald allows the reader to sense the narrator's implicit satire on Gatsby's "brand new name" and his ready sympathy for Gatsby's tough past. FIS, whose characteristic features are more in line with the form of narrative report, permits the narrator's voice to intermingle with that of the character's, such as what we see in paragraph 2 quoted above. Readers are offered the narrator's imaginative conception of Gatsby's background in this paragraph, with slight admiration, implicit sign of pity as well as irony. Hence, a single instance of FIS performs the two somewhat converse functions of irony and empathy.

\section{Free Direct Speech (FDS)}

Free direct speech is still another speech mode Fitzgerald uses to achieve special stylistic effects, though it is comparatively rarely used.

In The Great Gatsby, there is a paragraph recording an afternoon meeting when Tom Buchanan together with a man named Sloane and a pretty woman drops in:

He was profoundly affected by the fact that Tom was there. But he would be uneasy anyhow until he had given them something, realizing in a vague way that that was all they came for. Mr. Sloane wanted nothing. A Lemonade? No, thanks. A little champagne? Nothing at all, thanks.... I'm sorry ... (p. 98)

The passages preceding or following this extract are Direct Speech; here, Free Direct Speech seems deviant. In contrast to DS's loud acoustic effect, Free Direct Speech sounds like a murmur, subtly indicting Gatsby's sense of inferiority to Tom in wealth and status, his diffidence as Daisy's lover, and his tension and discomposure before he is moved by an irresistible impulse to tell Tom his relation with Daisy.

Another place where Free Direct Speech is dominant is when Jordan Baker recalls love between Daisy and Gatsby, 
which is the first time the narrator has the chance to "dispel" Gatsby's myth.

... The officer looked at Daisy while she was speaking, in a way that every young girl wants to be looked at some time, and because it seemed romantic to me I have remembered the incident ever since .... (p. 73)

The narrator is, at this moment, a highly involved listener -- he has no intention to interfere and thus lets the character's words burst out, suspending the flow of his original narrative. This cleverly exemplifies the narrator's long-pressed strong curiosity aroused by the prevailing rumors about Gatsby.

Still in Baker's narrative, we can see how FDS interacts with other speech modes to produce special effects.

I was a bridesmaid. I came into her room half an hour before the bridal dinner, and found her lying on her bed as lovely as the June night in her flowered dress -- and as drunk as a monkey. She had a bottle of Sauterne in one hand and a letter in the other.

"Gratulate me," she muttered. "Never had a drink before, but oh how I do enjoy it."

"What's the matter, Daisy?"

I was scared, I can tell you; I'd never seen a girl like that before.

"Here, deares". She groped around in a waste-basket she had with her on the bed and pulled out the string of pearls. “Take'em down-stairs and give'em back to whoever they belong to. Tell'em all Daisy's change' her mine. Say: 'Daisy's change' her mine!'

She began to cry --she cried and cried. I rushed out and found her mother's maid, and we locked the door and got her into a cold bath. She wouldn't let go of the letter. She took it into the tub with her and squeezed it up into a wet ball, and only let me leave it in the soap-dish when she saw that it was coming to pieces like snow. (p.74)

FDS surely makes Baker's narrative more smooth, and enables her to reveal directly her subconscious mental movements as well as her attitude towards love between Daisy and Gatsby, just as in "I was scared, I can tell you; I'd never seen a girl like that before". Besides, in this excerpt, FDS does in a sense form a "background" to the words in Direct Speech which, with greater immediacy and auditory impact, naturally call for strong emphasis and arouse deep sympathy for Daisy. Obviously the direct and free direct forms are here resorted to by the author to vary the distance of a single speech act.

To sum up, in The Great Gatsby, the author successfully preserves the smooth narrative pace with brevity and economy while achieving vivid characterization and excellent acoustic effects through DS. Shifts from DS, a mode that predominates throughout, to IS, FDS, or FIS serve to provide more stylistic variety, and the contrasts among them enable the author to control the highlighting and back-grounding of speeches according to the role and attitude of characters. Meanwhile the distance between the narrator, the narrated and the reader is dealt with masterly through the alternating use of different speech modes. It is the author's capacity to combine these different kinds of speech modes that enables his narrator to narrate so powerfully the characters he describes, to come close enough to sympathize with Gatsby's ambitions while keeping the distance. In other words, through the employment of different modes of speech presentation, the author achieves vivid characterization, accomplishes his desired distance (thus showing his stance clearly -- there is something deeply compassionate and ironic at the same time in the narrator's tone), and reveals the theme of the American Dream and American Disillusion well. By means of the designed speech devices in the novel, the author's storytelling is accomplished.

\section{REFERENCES}

[1] Associated Content. (2004). T. S. Eliot's genre, writing style, issues and their relevance today. http://www. associatedcontent. com/article/119569/ts_eliots_genre_writing_style

[2] Baughman, Judith S. and Broccoli, Matthew J. (2000). Literary Masters Series (Vol.1 Fitzgerald). Farmington Hills, Michigan: The Gale Group.

[3] Berman, Ronald. (2001). Fitzgerald, Hemingway, and the Twenties. London: the University of Alabama press.

[4] Bewley, Marius. (1963). Scott Fitzgerald's criticism of America. In. Mizener, Arthur. (Ed.) F. Scott Fitzgerald: A Collection of Critical Essays (p. 125). Englewood Cliffs: Prentice-Hall.

[5] Booth, Wayne C. (1961). The Rhetoric of Fiction. Harmondsworth: Penguin Books Ltd.

[6] Bruccoli, Matthew J. (1971). ed. Profile of F. Scott Fitzgerald. Columbus, Ohio: Merrill.

[7] Bruccoli, Matthew J. (1985). ed. New Essays on The Great Gatsby. Cambridge: Cambridge University Press.

[8] Bullock, Alan, Oliver S. Brass and Stephen Trombley. ed. (1988). The Fontana Dictionary of Modern Thought. Fontana Press.

[9] Callahan, John. F. (1972). The Illusion of a Nation: Myth and History in the Novel of F. Scott Fitzgerald. Illinois: University of Illinois Press.

[10] Carter, Ronald and Paul Simpson. (1995). Language, Discourse, and Literature: An Introductory Reader in Discourse Stylistics. London: New York Taylor\& Francis Routledge.

[11] Cooperman, Stanley. (1996). Scott Fitzgerald's The Great Gatsby.

[12] Cowley, Malcolm and Robert Cowley. (1966). ed. Fitzgerald and the Jazz Age. New York: Scribners.

[13] Donaldson, Scott. ed. (1984). Critical Essays on F. S. Fitzgerald's The Great Gatsby. Boston: G.K.Hall.

[14] Eble, Kenneth. ed.(1973). F. Scott Fitzgerald: A Collection of Criticism. New York: McGraw-Hill.

[15] Fitzgerald, Francis Scott. (2003). The Great Gatsby. Qingdao: Qingdao Press

[16] Hook, Andrew. (2002). F. Scott Fitzgerald: a literary life. Basingstoke: Palgrave Macmillan.

[17] Jakobson, Roman. (1976). Linguistics and poetics. In. Chatman S. \& Levin S. (Ed.) Essays on the Language of Literature (pp.299-303). 
[18] Leech, G. N. and M. H. Short. (2000). Style in Fiction: A Linguistic Introduction to English Fictional Prose. Beijing: Foreign Language Teaching and Research Press.

[19] Long, Robert Emmet. (1979). The Achieving of The Great Gatsby. Lewisburg Pa.: Bucknell University Press.

[20] Miller, James E., Jr. (1964). F. Scott Fitzgerald: His Art and His Technique. New York: New York University Press.

[21] Mizener, Arthur. ed. (1963). F. Scott Fitzgerald: A Collection of Critical Essays. Englewood Cliffs: Prentice-Hall.

[22] Neufeldt, Victoria and David b. Guralnik. ed. (1997). Webster's New World College Dictionary. Macmillan.

[23] Thornborrow, Joanna. (2000). Patters in Language: Stylistics for Students of Language and Literature. Beijing: Foreign language Teaching and Research Press.

[24] Tory, William. (1945). Scott Fitzgerald-the authority of failure. In Arthur Mizener (Ed.). F.Scott Fitzgerald - A Collection of Critical Essays. Englewood Cliffs, NJ: Prentice-Hall

[25] Piper, Henry Dan. ed. (1970). Fitzgerald's The Great Gatsby: The Novel, the Critics, the Background. New York: Scribners.

[26] Posnock, Ross. (1984). Fitzgerald's critique of capitalism in The Great Gatsby. In. Donaldson, Scott. (Ed.) Critical Essays on F. S. Fitzgerald's The Great Gatsby. Boston: G.K.Hall.

[27] Pelzer, Linda Claycomb. (2000). Student Companion to F. Scott Fitzgerald. Westport, Conn: Greenwood Press.

[28] Prigozy, Ruth. ed. (2001). The Cambridge Companion to F. Scott Fitzgerald. Cambridge: Cambridge University Press.

[29] Wikipedia, the free encyclopedia. http://en. Wikipedia.org/wiki/Charles_Dickens

[30] Wright, Laura \& Hope, Jonathan. (2000). Stylistics: A Practical Coursebook. Beijing: Foreign Languages Teaching and Research Press.

Xiangqi Liu was born in Qingdao, China in 1978. She received her master degree in linguistics from Ocean University of China, Qingdao, China in 2009.

She is currently a lecturer in the School of Foreign Languages, Qingdao University of Science and Technology, Qingdao, China. Her research interests include stylistics and Chinese American literature. 